\title{
Microhardness Investigation of Dental Composite Resins Exposed to Corrosive Environment
}

\author{
CRISTINA-ANGELA GHIORGHE ${ }^{1}$, VLAD CARLESCU1*, CLAUDIU TOPOLICEANU ${ }^{1 *}$, IRINA NICA ${ }^{1}$, GALINA PANCU $^{1}$, \\ GIANINA IOVAN ${ }^{1}$, SORIN ANDRIAN ${ }^{1}$, COSTIN LUPU ${ }^{2}$ \\ ${ }^{1}$ Grigore T. Popa University of Medicine and Pharmacy, Faculty of Dental Medicine, 16 Universitatii Str., 700115, Iasi, Romania \\ ${ }^{2}$ Gheorghe Asachi Technical University of lasi, Faculty of Mechanics Department of Mechanical Engineering, Mechatronics and \\ Robotics, Bld. D. Mangeron nr. 43, 700050, Iasi, Romania
}

\begin{abstract}
The aim of this study was to evaluate the microhardness Rockwell and Young's modulus of a new nanohybrid and nano-fill composite resins exposed to corrosive media. The study was performed on two composite resins, one nano-hybrid and one nano-fill, enamel, dentine, translucent, respectively body shade, of which were made 20 samples ( $25.0 \pm 0.1 \mathrm{~mm}$ lengths, $10.0 \pm 0.1 \mathrm{~mm}$ widths and $3.0 \pm 0.1 \mathrm{~mm}$ thicknesses), which were immersed in mouthwash for 1 minute per day for 10 days, the rest of the time being stored in artificial saliva. Measurements of Rockwell microhardness and Young's modulus on samples were made between on the first day, after 6 days and 10 days of immersion in mouthwash comparative with 0 day. The results showed that after immersion in the corrosive environment, both materials had the hardness values changed, but medium values of Rockwell microhardness to nano-fill composite resin were higher than nano-hybride. At the nano-hybride composite resin, it was observed that the enamel and clear translucent groups had the mean values increased after the first day of exposure to mouthwash, compared to the dentine group, which showed a higher mean value after 6 days. At the nano-fill composite resin, for the enamel and body groups were obtained the higher values of HRC after 10 days. For the dentine group, after 6 days, Filtek Ultimate showed the same variation as Harmonize dentine shade. Harmonize composite resin showed higher values of Rockwell microhardness and Young's modulus for all study groups compared to Filtek Ultimate.
\end{abstract}

Keywords: nano-hybrid composite resin, nano-fill composite resin, the microhardness Rockwell and Young's modulus, corrosive media

The use of coronary restoration materials from composite resins has a wide spread in the world, being indicated on both the front and the lateral teeth [1]. Patients' preferences for aesthetic restorations, as well as the application of minimally invasive treatment for dental caries, have made the indications of composite resins increasing. For the use of these materials in the lateral area, it was necessary, over time, to improve the mechanical and chemical performance [2]. Many studies have shown that wear of composite resins is one of the reasons for fracture that can occur at restorations on lateral teeth $[3,4]$. These lateral restorations are subject to mechanical forces and chemical changes, such as chewing harsh foods or bruxism [5-7].

If the forces applied to composite resin restorations outweigh the mechanical strength of the material, wear may occur, which is mostlikely to occur in patients applying force higher than average during mastication [8]. Also, these forces can cause the appearance of rough surfaces and surface defects in restorations [9].

Corrosion is due to a chemical reaction between the surface and the environment [10]. A number of studies have shown that a corrosion reaction can be initially rapid butthen itcan form a cohesive layer of the reaction product, which protects the surface of the base. The cohesive layer may be easily removed if there is a contact with another hard object (dental cusp or another restoration), which makes the unreacted starting material still to be exposed to corrosion or corrosive wear. Restorations in the oral cavity are exposed to potentially corrosive chemicals in foods, beverages, microbes and saliva [11, 12]. The acids in the bacterial plaque, food constituents and the enzymes have been shown to damage the surface and may increase the vulnerability of composite resins to abrasive wear [6]. On the other hand, saliva can have a buffering effect, reducing the acidity resulting from food fermentation and bacterial activity [13].

Resistance of composite materials to wear and corrosion depends on the hardness of the materials. This can be defined as the measurement of resistance to plastic deformations [14].

Restorations of composite resins indicated for the front area, besides its aesthetic properties, must also meet mechanical properties such as microhardness, flexural strength. By altering the size, shape and distribution of the fillers, as well as the composition of the polymers from the organic matrix, were obtained the composite materials of high aesthetic and mechanical performance. Rockwell microhardness is an indentation hardness test using a verified machine to force a diamond spheroconical indenter or tungsten carbide (or steel) ball indenter, under specified conditions, into the surface of the materials under test, and to measure the difference in depth of the indentation as the force of the indenter is increased from a specified preliminary test force to a specified total test force and then return to the preliminary test force [15]. The advantages of the Rockwell hardness test are that hardness is read directly and it is good for testing viscoelastic materials [16, 17].

The aim of our study was to determine microhardness Rockwell and Young's modulus of a nano-hybrid and nanofill composite resins, enamel, dentin, translucent and body shades exposed to corrosive media for 1 minute per day,

*email: carlescu.vlad@yahoo.com; claudiutopoliceanu@yahoo.com 
to 10 days, the rest of the time being stored in artificial saliva. Measurements of Rockwell microhardness and Young's modulus on samples were made between on the first day, after 6 days and 10 days of immersion in mouthwash comparative with 0 day.

\section{Experimental part}

\section{Materials and methods}

The materials tested in this study were composite resin nano-hybride Harmonize (Kerr Corporation) shade enamel, dentine and clear translucent and nano-fill Filtek Ultimate (3M ESPE, USA) shade enamel, dentine and body (table 1).

There were 6 study groups: HE - Harmonize enamel; HD - Harmonize dentin; HT- Harmonize translucent and respectively FUE - Filtek Ultimate enamel; FUD - Filtek Ultimate dentin; FUB - Filtek Ultimate body. Twenty samples from each group were prepared, the materials being condensed into rectangular bar-shaped specimens (25.0 $\pm 0.1 \mathrm{~mm}$ length, $10.0 \pm 0.1 \mathrm{~mm}$ width and $3.0 \pm 0.1$ $\mathrm{mm}$ thickness) using a custom holder. A constant excess of uncured resin composite was placed into the mould, covered with a cellulose acetate strip and a glass microscope slide and a weight of $1 \mathrm{~kg}$ was applied for $20 \mathrm{~s}$ to ensure consistent and reproducible packing of the specimens. The weight and microscope slide were removed and the specimen was light irradiated both the top and the lower surface using a lightemitting diode (LED) light curing unit (LCU) (DTE Lux E-Guilin Woodpecker Medical Instrument Co. Ltd. China) at ambient room temperature $\left(23 \pm 1^{\circ} \mathrm{C}\right)$ with a spectral range of $420-480$ $\mathrm{nm}$ and an irradiance of $1200 \mathrm{~mW} / \mathrm{cm}^{2}$. The entire length of each specimen was light irradiated using the ISO 4049 specimen manufacture protocol by placing the tip of the light guide in direct contact with the cellulose acetate strip in the centre of the specimen [18]. Following light irradiation, the specimens were polished with abrasive tape with a grain size of up to 1200 under cooling with water. The samples were kept in distilled water at room temperature for 7 days. Then the study lots were immersed in Listerine ${ }^{\circledR}$ Total Care mouthwash for 1 minute per day for 10 days, the rest of the time being stored in artificial saliva ( $p \mathrm{H}=6.7$ ).

The Listerine ${ }^{\circledR}$ Total Care Fresh Mint Anticavity Mouthwash solution (Listerine ${ }^{\circledR}$ ) has a $\mathrm{pH}$ of 4.35 and the composition: Sodium fluoride $0.02 \% ; 0.01 \% \mathrm{w} / \mathrm{v}$ fluoride ion); Water; sorbitol; Alcohol (21.6\% v/v); Poloxamer 407; Sodium Saccharin; Flavor; eucalyptol; Methyl Salicylate; thymol; Phosphoric Acid; Menthol; Disodium Phosphate; sucralose; Red 40; Blue 1.

Measurements of Rockwell microhardness and Young's modulus on samples were made between on the first day, after 6 days and 10 days of immersion in Listerine comparative with 0 day.

Rockwell microhardness of resin specimens was evaluated by using Tribometer UMT-2 (CETR) showed in figure 1. Rectangular specimens $(25 \times 10 \times 3 \mathrm{~mm})$ were fixed on the linear table of the tribometer and indented with a preliminary test force of $1 \mathrm{~N}$ for $15 \mathrm{~s}$ and a total test force of

Table 1

MATERIALS TESTED IN THIS STUDY

\begin{tabular}{|c|c|c|}
\hline Materials & Composition monomer & Filler \\
\hline $\begin{array}{c}\text { Harmonize (KERR) } \\
\text { nano-hybride composite }\end{array}$ & $\begin{array}{l}\text { BisGMA } \\
\text { BisEMA } \\
\text { TEGDMA }\end{array}$ & $\begin{array}{l}\text { Spherical silica and zirconia particles } 5-400 \mathrm{~nm} \text { formed from a } \\
\text { molecular suspension in Adaptive Response Technology (ART); } \\
\text { barium glass (inorganic filler } 81 \% \text { weight; } 64.5 \% \text { volume) }\end{array}$ \\
\hline $\begin{array}{l}\text { Filtek Ultimate } \\
(3 \mathrm{M} \text { ESPE, USA) } \\
\text { nano-fill composite }\end{array}$ & $\begin{array}{l}\text { Bis-GMA } \\
\text { UDMA } \\
\text { TEGDMA } \\
\text { Bis-EMA6 }\end{array}$ & $\begin{array}{l}\text { Non-agglomerated/non aggregated } 20 \mathrm{~nm} \text { silica filler, non- } \\
\text { agglomerated/non-aggregated } 4 \text { to } 11 \mathrm{~nm} \text { zirconia filler, and } \\
\text { aggregated zirconia/silica cluster filler } \\
\text { The Dentin, Enamel and Body (DEB) } 3 \text { shades have an average cluster } \\
\text { particle size of } 0.6 \text { to } 10 \text { microns. (inorganic filler } 78.5 \% \text { by weight; } \\
63.3 \% \text { by volume) }\end{array}$ \\
\hline & & \\
\hline
\end{tabular}

Table 2

COMPOSITION ARTIFICIAL SALIVA $(\mathrm{pH}=6.7)[18]$

\begin{tabular}{|c|c|}
\hline $\mathrm{KCL}$ & $1.5 \mathrm{~g}$ \\
\hline $\mathrm{NaHCO}_{3}$ & $1.5 \mathrm{~g}$ \\
\hline $\mathrm{NaH}_{2} \mathrm{PO}_{4}$ & $0.5 \mathrm{~g}$ \\
\hline KSCN & 0.5 \\
\hline Lactic acid & $0.7 \mathrm{~g}$ \\
\hline
\end{tabular}
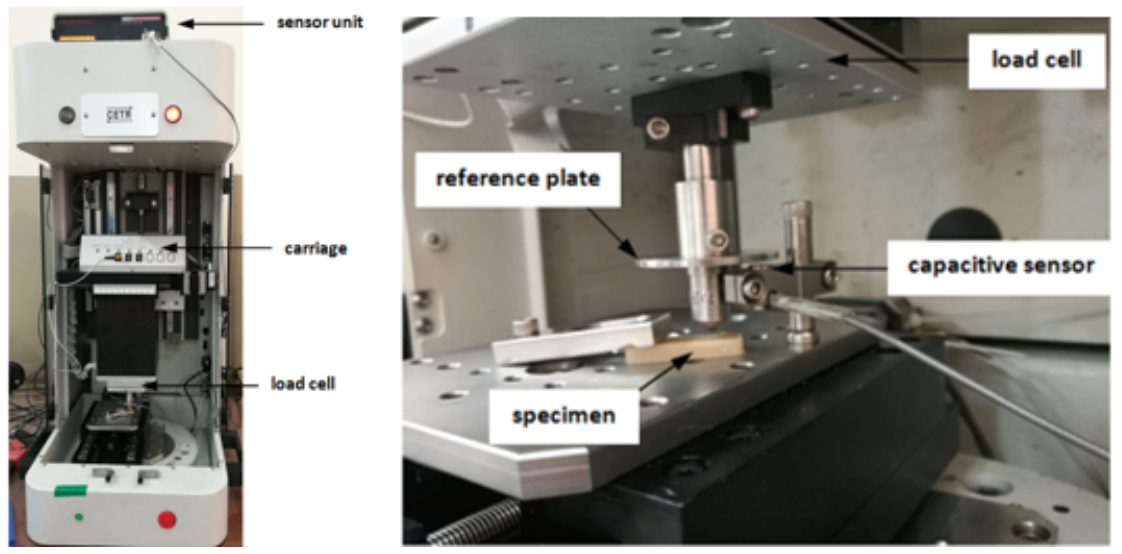

Fig.1. Tribometer UMT-2 (CETR) 


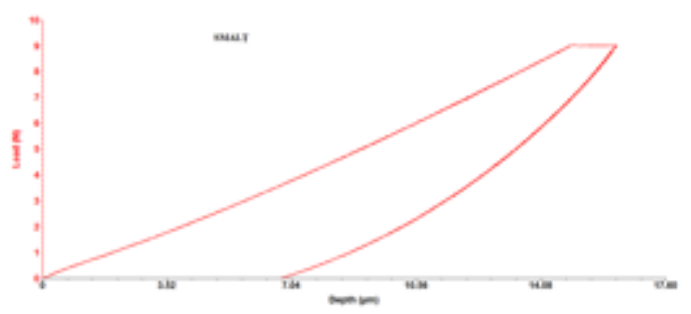

a.

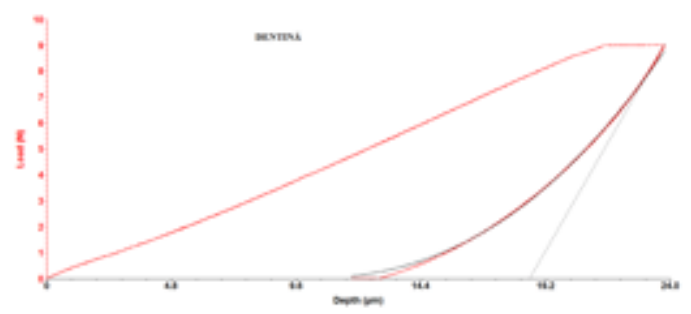

b.

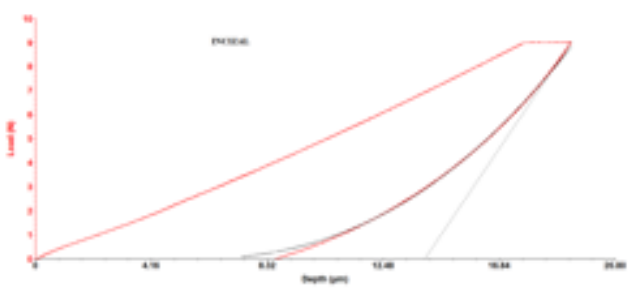

Fig.2. Microindentation graph for HE (a), HD (b), HT (c)

$10 \mathrm{~N}$ for $30 \mathrm{~s}$. A diamond spheroconical indenter with tip radius of $200 \mathrm{im}$ was pressed on the surface of the samples with an indentation velocity of $0.005 \mathrm{~mm} / \mathrm{s}$. The depth of penetration was recorded by a capacitive displacement sensor. The viewer software of Tribometer is able to automatically calculate the indentation parameters, the Young's modulus and the hardness ( $\mathrm{HRC}-\mathrm{kgf} / \mathrm{mm}^{2}$ ) is evaluated from the slope of the unload phase (figs. 2 and 3).

\section{Results and discussions}

The results of the Rockwell microhardness measurements and the Young's modulus on the Harmonize (KERR) nano-hybrid composite material on the studies groups over the three assessment periods are presented in Table 3.

For the HE group, mean values were to 1 day (68.182 $\left.\mathrm{kgf} / \mathrm{mm}^{2}\right)$ higher than the control group $\left(63.877 \mathrm{kgf} / \mathrm{mm}^{2}\right)$, and for the 6 days $\left(59.426 \mathrm{kgf} / \mathrm{mm}^{2}\right)$ and 10 days ( 63.403 $\mathrm{kgf} / \mathrm{mm}^{2}$ ) smaller. Young's modulus to HE showed the following mean values: 1 day (21.951 GPa) > control $(20.764 \mathrm{GPa})>10$ day $(20.491 \mathrm{GPa})>6$ day $(20.048 \mathrm{GPa})$.

The results obtained in the HD group showed that mean HRC values of 1 day $\left(50.474 \mathrm{kgf} / \mathrm{mm}^{2}\right)$ and 10 days of testing $\left(49.168 \mathrm{~kg} / \mathrm{mm}^{2}\right)$ were lower than the control group $\left(52.654 \mathrm{kgf} / \mathrm{mm}^{2}\right)$.
I he average $\mathrm{HKC}$ values at $\mathrm{b}$ days $\left(53.696 \mathrm{kgf} / \mathrm{mm}^{2}\right)$ was higher than in the control group, which means that by exposure to mouthwash, the surface of the sample has undergone a corrosive softening and has been removed, and the underlying layer by maintaining in the artificial saliva has had a higher resistance to the control sample.

The mean values for Young's modulus in the HD group were: 6 day $(17.929 \mathrm{GPa})>$ control $(16.040 \mathrm{GPa})>1$ day $(15.976 \mathrm{GPa})>10$ day (15.699 GPa). For HT samples the data showed the following values: in the control group $\left(50.372 \mathrm{kgf} / \mathrm{mm}^{2}\right)$, after 1 day $\left(51.425 \mathrm{kgf} / \mathrm{mm}^{2}\right), 6$ days $\left(49.984 \mathrm{kgf} / \mathrm{mm}^{2}\right)$ and 10 days $\left(47.333 \mathrm{kgf} / \mathrm{mm}^{2}\right)$. For the HT group, mean Young's modulus values were: 1 day $(17.985 \mathrm{GPa})>6$ day $(17.605 \mathrm{GPa})>$ control $(17.350 \mathrm{GPa})$ $>10$ day (16.369 GPa).

It is noted that the enamel and clear translucent groups had the mean values increased after the first day of exposure to Listerine, compared to the dentine group, which showed a higher mean value after 6 days.

The results of the Rockwell microhardness and Young's modulus for the Filtek Ultimate (3M ESPE) nano-fill composite material are presented in table 4.

The mean HRC hardness values of the FUE samples were in the following decreasing order: 10 day (57.846 $\left.\mathrm{kgf} / \mathrm{mm}^{2}\right)>$ control $\left(56.248 \mathrm{kgf} / \mathrm{mm}^{2}\right)>6$ day $(54.167$ $\left.\mathrm{kgf} / \mathrm{mm}^{2}\right)>1$ day $\left(36.642 \mathrm{kgf} / \mathrm{mm}^{2}\right)$. For Young's modulus at FUE, the mean values were: 10 day $\left(17.544 \mathrm{kgf} / \mathrm{mm}^{2}\right)$

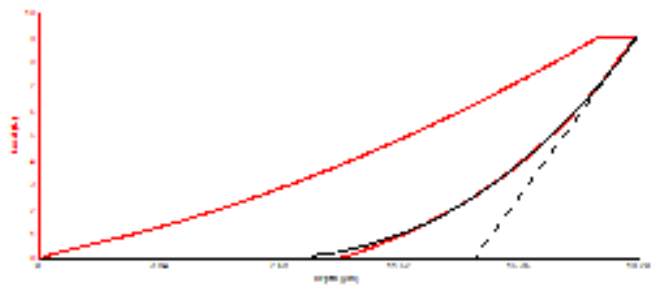

a.

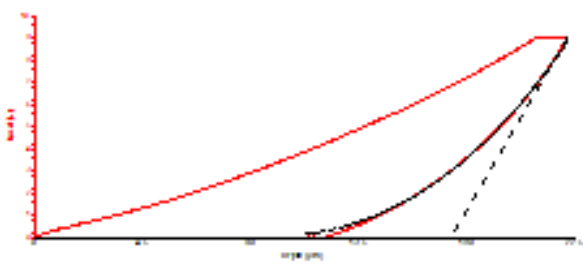

b.
Fig.3. Microindentation graph for FUE (a), FUD (b), FUB (c)

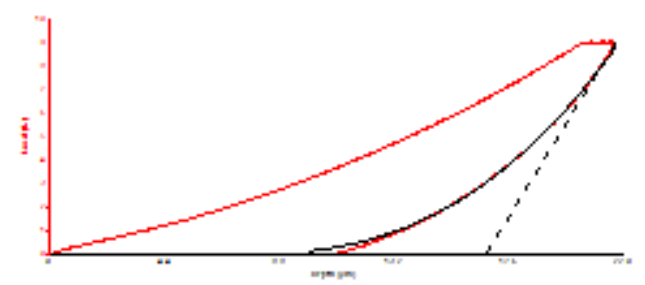




\begin{tabular}{|c|c|c|c|}
\hline MATERIALS & & HRC (kgf/mm $\left.{ }^{2}\right)$ & YoungModulus (GPa) \\
\hline $\begin{array}{c}\text { HARMONIZE } \\
\text { KERR }\end{array}$ & & \multicolumn{2}{|c|}{ Mean \pm SD } \\
\hline \multirow{4}{*}{ HE } & control & $63.877 \pm 2.568$ & $20.764 \pm 1.184$ \\
\hline & 1 day & $68.182 \pm 0.311$ & $21.951 \pm 0.127$ \\
\hline & 6 days & $59.426 \pm 0.872$ & $20.048 \pm 0.302$ \\
\hline & 10 days & $63.403 \pm 2.608$ & $20.491 \pm 0.466$ \\
\hline \multirow{4}{*}{$\mathrm{HD}$} & control & $52.654 \pm 3.987$ & $16.04 \pm 1.669$ \\
\hline & 1 day & $50.474 \pm 1.337$ & $15.976 \pm 0.813$ \\
\hline & 6 days & $53.696 \pm 8.593$ & $17.929 \pm 2.002$ \\
\hline & 10 days & $49.168 \pm 8.304$ & $15.699 \pm 2.928$ \\
\hline \multirow{4}{*}{ HT } & control & $50.372 \pm 1.621$ & $17.350 \pm 0.863$ \\
\hline & 1 day & $51.425 \pm 0.311$ & $17.985 \pm 0.385$ \\
\hline & 6 days & $49.984 \pm 2.850$ & $17.605 \pm 0.446$ \\
\hline & 10 days & $47.333 \pm 0.960$ & $16.369 \pm 0.188$ \\
\hline
\end{tabular}

Table 3

DESCRIPTIVE STATISTIC ROCKWELL MICROHARDNESS ANDYOUNG'S MODULUS TO HARMONIZE

\begin{tabular}{|c|c|c|c|}
\hline MATERIALS & & HRC $\left(\mathrm{kg} / \mathrm{mm}^{2}\right)$ & \multicolumn{2}{|c|}{ YoungModulus (GPa) } \\
\hline \multirow{2}{*}{$\begin{array}{c}\text { ULTILTEK } \\
\text { 3M ESPE }\end{array}$} & & & \\
\hline \multirow{4}{*}{ FUE } & control & $56.248 \pm 0.132$ & $16.814 \pm 1.053$ \\
\cline { 2 - 4 } & 1 day & $36.642 \pm 0.160$ & $11.283 \pm 2.054$ \\
\cline { 2 - 4 } & 6 days & $54.167 \pm 0.195$ & $16.258 \pm 1.641$ \\
\cline { 2 - 4 } & 10 days & $57.846 \pm 0.152$ & $17.544 \pm 1.289$ \\
\hline \multirow{4}{*}{ FUD } & control & $45.821 \pm 0.086$ & $14.803 \pm 3.851$ \\
\cline { 2 - 4 } & 1 day & $45.385 \pm 0.307$ & $12.946 \pm 3.166$ \\
\cline { 2 - 4 } & 6 days & $56.973 \pm 0.303$ & $17.086 \pm 2.918$ \\
\cline { 2 - 4 } & 10 days & $42.313 \pm 0.372$ & $16.803 \pm 4.625$ \\
\hline \multirow{3}{*}{ FUB } & control & $52.199 \pm 0.033$ & $16.704 \pm 0.935$ \\
\cline { 2 - 4 } & 1 day & $55.513 \pm 0.110$ & $16.775 \pm 1.098$ \\
\cline { 2 - 4 } & 6 days & $54.091 \pm 0.185$ & $17.383 \pm 7.072$ \\
\cline { 2 - 4 } & 10 days & $60.596 \pm 0.078$ & 0.434 \\
\hline
\end{tabular}

Table 4

DESCRIPTIVE

STATISTIC

ROCKWELL MICROHARDNESS

ANDYOUNG'S

MODULUS TO FILTEK ULTIMATE
$>$ control $\left(16.814 \mathrm{kgf} / \mathrm{mm}^{2}\right)>6$ day $\left(16.258 \mathrm{kgf} / \mathrm{mm}^{2}\right)>$ 1 day $\left(11.283 \mathrm{kgf} / \mathrm{mm}^{2}\right)$.

For the FUD group, mean HRC values were: 6 day $\left(56.973 \mathrm{kgf} / \mathrm{mm}^{2}\right)$ control $\left(45.821 \mathrm{kgf} / \mathrm{mm}^{2}\right)>1$ day $\left(45.385 \mathrm{kgf} / \mathrm{mm}^{2}\right)>10$ day $\left(42.313 \mathrm{kgf} / \mathrm{mm}^{2}\right)$. For Young's modulus, the order is the same as HRC.

The mean HRC FUB values were in the following order: 10 day $\left(60.596 \mathrm{kgf} / \mathrm{mm}^{2}\right)>1$ day $\left(55.513 \mathrm{kgf} / \mathrm{mm}^{2}\right)>6$ day $\left(54.091 \mathrm{kgf} / \mathrm{mm}^{2}\right)>$ control $\left(52.199 \mathrm{kgf} / \mathrm{mm}^{2}\right)$. Young's modulus values kept the same order.

From our results, we can see that the mean HRC values of the HE group, compared to those of the FUE group, were higher in the control group, the 6 days and 10 days, respectively. An important decrease at mean HRC values was observed in the 1 day FUE group that showed significantly lower values than $\mathrm{HE}$.

The HD samples showed higher values at mean HRC than FUD in control groups, 1 day and 10 days. On the other way, at the samples HD to 10 days, we observed lower values at mean HRC than the samples FUD to the same period.

Compared to Filtek Ultimate, Harmonize contains an amount of 400 nanometer barium glass particles. This combination helps provide strength, polishability, radiopacity, wear resistance and ideal viscosity and handling.

Harmonize was introduced Adaptive Response Technology (ART) in which zirconium and silica nanoparticles are in an arrangement that confers special optical properties. At the same time, the ART filler system is a rheological modifier, which acts as a stabilizing network if left uninterrupted. The special ART filler network of Harmonize is made of very small (nano-scale) particles of Silica and Zirconium that are linked together and fused in a reinforced structure. These particles bond together (they have opposite charge), in addition the reinforced filler network ensures an efficient bond / interactivity effect between the filler cluster and the resin delivering an overall enhanced structural integrity with better long term performances (superior strength).

Manufacturers have specified that the apparent viscosity of the material is higher, which prevents its creep, but can also explain an increase in hardness. The fillers of Harmonize seem to be similar to pre-polymerized fill. It is still an agglomeration such as pre-polymerized fill (a particle group), but it cleans very well with the resin. The advantages were: high load, low wear, low shrinkage, good resistance and non-sticky handling. The filler system in Harmonize is made almost exclusively of nano-scale material, and the average particle size is less than 50 nanometers. The primary filler is composed of 5 nanometer zirconium particles and 20 nanometer silica particles. These are formed from a molecular suspension into small spherical shapes. Then, these nano-scale particles are formed into clusters 2-3 microns in diameter thatare joined by a reinforcing structure.

Chung[20] observed that the filler content of composite material does not influence wear but other mechanical properties, such as diametric tensile strength and Knoop hardness.

The commercial dental composite which contain BisGMA was high viscosity when is mixed with TEGDMA. 
UDMA corresponds to another alternative organic matrix composition and it is often present in current compositions [21].

Söderholm et al. [22] considered the urethane-base composites performed significantly better wear resistance than those which were bisGMA-based over three years clinical observation.

In a study of 3 aesthetic composite materials the authors reported that the composites that include pre-polymerized fillers (Clearfil-nanohybrid and G Aenial Anterior microhybrid) exhibited significantly lower microhardness values [23].

Blackham etal. [24] reported that pre-polymerized fillers that contained composites (Gradia Direct Posterior, Premise) performed worse in strength tests than traditional hybrid composites (Z250, Esthet-X).

Nanofillers and nanoclusters contribute to the stability of long-term composite resins and the possibility of better finishing. The mechanical stability of these composite resins is due to the size and dispersion of the filler particles [25]. The most current composites are filled with silicate particles based on oxides of barium, strontium, zinc, aluminium or zirconium. The concentration rate of filler is generally $70 \%-80 \%$ by weight. The particle filler size is in the range from 0.04 to $85 \mathrm{im}$ [26]. Filler particles play a role in enhancing composite resistance and reducing the amount of matrix material, resulting in increased hardness, decreased wear and reduced polymerization shrinkage [27]. The filler content, filler size, morphology, and the distribution of filler particles influence the physical and mechanical properties of composite resin and manystudies reported the relation between filler and flexural strength, compressive strength, diametral tensile strength, shear punch strength, fracture toughness, hardness, wear, shrinkage stress and thermal expansion [28-30].

The hardness of composite materials can be influenced by the size and volume of inorganic particles [31]. Decreasing the particle size of the filler particles is a better dispersion pattern and an interfacial surface increased betw een the matrix and the filler. By the smaller size of the filling particles an increased bending strength, surface microhydration and polishability of the final restoration are obtained [32].

On the other hand, the hardness of the resin composite may be affected by acid attack [33, 34]. Composite resins suffer a softening of the surface layer under the action of acids due to changes in the organic component [35]. Wongkhantee etal. [35] observed thatorganic acids induce BIS-GMA dissolution.

Nica et al. [36] in a study, argue that composite resins can suffer chemical corrosion which affected polymeric matrix and filler particles in acid medium. Fillers are made of quartz, ceramic and/or silica. By increasing the filler content, the polymerization shrinkage, the linear expansion coefficient and the water absorption are reduced. On the other hand, it can lead to increased compressive and tensile strength, modulus of elasticity and wear resistance [37]. The filler content of a composite is sometimes determined by the shape of the filler. In a study of different types of composites, those materials with pre-polymerised composite fillers exhibited the smallest filler content and thus also the lowest flexural strength and hardness. Composites with rounded fillers had the highest filler content, which was associated with higher hardness and high bending strength. For mixed filler particles (hybrid composites) there was no linear relationship between filler content and bending strength [38,39]. In a study of 72 repair materials, it was also shown that the volume of filler had a significant influence on the mechanical properties.
The relationship between filling content, bending strength and modulus of elasticity was very evident [40].

According to Kim et al.'[41] filler morphology and loading influenced mechanical properties of composites such as flexural strength and microhardness. The researchers reported that pre-polymerized filler particle containing composites had significantly lower flexural strength compared with other composites. Pre-polymerized resin filler is primarily added into composites to reduce dimensional change during polymerization and to reduce the amount of unpolymerized resin [42, 43]. However, use of pre-polymerized filler might result in an actual lower percentage of filler, which may result in poorer mechanical properties. Filtek Ultimate incorporates zirconium particles; higher microhardness values of this composite resin may be related with zirconia filler. Also, filler distribution or dimensions could affect hardness results $[44,45]$.

Moraes et al. [46] reported that nano-hybrid resins generally demonstrated inferior properties compared with nano-filled composites, and the behavior of nano-hybrid resin composites was more closely related to that of microhybrid than nano-filled materials.

The decreasing mechanical properties of materials after water storage results from the separation of polymer chains by water molecules [47]. Water can cause the degradation of dental composites by weakening the silane interface and leaching filler particles, or softening the organic matrix due hydrolysis. Both effects result in a decrease of mechanical properties of composites. In a study, Bauer et al. [48] reported that 4-week aging in artificial saliva improved micro-mechanical properties such as Vickers hardness, as compared with 24-h water storage.

Cesar et al. [49] examined the flexural strength and microhardness values of composites after 30 days of water storage and showed that extended water storage negatively affected the hardness of all composites tested; however, it did not affect the flexural strength of most of the composites.

Another study of Sideridou et al. [ 50] reported that the mechanical properties of Bis-GMA showed no significant difference after immersion in water; however, UDMA resin showed a significant decrease between 0 and 30 days for both flexural (73\%) and tensile strength (85\%).

Ho et al. [51] reported that UDMA-based materials softened in water much more easily than Bis GMA-based materials.

\section{Conclusions}

At the nano-hybride composite resin, it was observed that the enamel and clear translucent groups had the mean values increased after the first day of exposure to mouthwash, compared to the dentine group, which showed a higher mean value after 6 days. At the nano-fill composite resin, for the enamel and body groups were obtained the higher values of HRC after 10 days. For the dentine group, after 6 days, Filtek Ultimate showed the same variation as Harmonize dentine shade. Harmonize composite resin showed higher values of Rockwell microhardness and Young's modulus for all study groups compared to Filtek Ultimate.

\section{References}

1.FERRACANE, J.L., Dent. Mater., 27, 2011, p. 29.

2.SARRETT, D.C., Dent. Mater., 21, 2005, p. 9.

3.DEMARCO, F.F., CORREAA, M.B., CENCI, M.S., MORAES, R.R., OPDAM, N. J.M., Dent. Mater., 28, 2012, p. 87.

4.BECK, F., LETTNER, S., GRAF, A., BITRIOL, B., DUMITRESCU, N., BAUER, P., MORITZ, A., SCHEDLE, A., Dent. Mater., 31, 2015, p. 958. 
5.DE GEE, A.J ., VAN DUINEN, R.M.B., WERNER, A., DAVIDSON, C.L., J. Dent. Res., 75, no. 8, 1996, p. 1613.

6.YAP, A.U., TEOH, S.H., CHEW, C.L., Dent. Mater., 18, 2002, p. 149.

7.FUJII, K., CARRICK, T.E., BICKER, R., MCCABE, J.F., Dent. Mater., 20, 2004, p. 931.

8.FERRACANE, J.L., Materials in dentistry: principle and application. Philadelphia: Lippincott Williams \& Wilkins, 2001, p. 293.

9.MAYW ORM, C.D., CAMARGO, JR S.S., BASTIAN, F.L., J. Dent., 36, 2008, p. 703.

10.DE PAULA, A.B., FUCIO, S.B., AMBROSANO, G.M., ALONSO, R.C., SARDI, J.C., PUPPIN-RONTANI, R.M., Oper. Dent., 36, 2011, p. 670. 11.TSUJ IMOTOA, A., BARKMEIER, W.W., FISCHER, N.G., NOJIRI, K., NAGURA, Y., TAKAMIZAWA, T., LATTA, M.A., MIAZAKI, M., Japanese Dental Science Review, 54, 2018, p. 76.

12.SAKAGUCHI, R.L., POWERS, J.M., Craig's Restorative Dental Materials Elsevier Mosby, Fundamentals of Materials Science, 2012, p. 33.

13.ILIE, N., HILTON, T.J ., HEINTZE, S.D., HICKEL, R., WATTS, D.C., SILIKAS, N., STANSBURY, J.W., CADENARO, M., FERRACANE, J.L., Dental Materials, 33, 2017, p. 880.

14.SAKAGUCHI, R.L., POWERS, J .M., Craig's Restorative Dental Materials Elsevier Mosby, Testing of Dental Materials And Biomechanics, 2012, p. 91.

15.GHIORGHE, C.A., IOVAN, G., CARLESCU, V., ISTRATE, B., PANCU, G., ANDRIAN, S., Rev. Chim. (Bucharest) 68, no.11, 2017, p. 2623.

16.*** International Organisation for Standardisation, ISO 4049: Dentistry - Polymer- based Filling, Restorative and Luting Materials, 3rd ed., 2000, p. 15.

17.BRETT, C.M.A., TRANDAFIR, F., J ournal of Electroanalytical Chemistry, 572, 2004, 347.

18.CHUNG, K.H., J. Dent. Res., 69, 1990, p. 852.

19.CAO, L., ZHAO, X., GONG, X., ZHAO, S., Int. J. Clin. Exp. Med., 6, no. 6,2013, p. 423.

20.SODERHOLM, K.J., LAMBRECHTS, P., SARRETT, D., ABE, Y., YANG, M.C., LABELLA, R., YILDIZ, E., WILLEMS, G., Eur. J. Oral SCi., 109, 2001, p. 273.

21.PALA, K, TEKCE, N., TUNCER, S., DEMIRCI, M., ÖZNURHAN, F., SERIM, M., J. Clin. Exp. Dent., 9, no 3, 2017, e424-30. http://dx.doi.org/ 10.4317/jced.53463

22.BLACKHAM, J.T., VANDEWALLE, K.S., LIEN, W., Oper. Dent., 34, 2009, p. 697.

23.ZANTNER, C, KIELBASSA, A.M., MARTUS, P., KUNZELMANN, K.H., Dent. Mater., 20, 2004, p. 277.

24.KAHLER, B., KOTOUSOV, A., SWAIN, M.V., Acta Biomaterialia 4, no.1, 2008, p. 165.

25.LU, H., LEE, Y.K., OGURI, M., POWERS, J.M., Operative Dentistry, 31, no. 6, 2006, p. 734.

26.TURSSI, C.P., FERRACANE, J.L., FERRACANE, L.L., J ournal of Biomedical Materials Research Part B: Applied Biomaterials, 78 B, no. 1, 2006, p. 196.

27.SAUNDERS, S., Clin Cosmet Investig Dent 1, 2009, p. 47. Dent. Res., 75, 1996, p.1613.
28.DE GEE, A.J ., WENDL, S.L., WERNER, A., DAVIDSON, C.L., Biomaterials, 17, 1996, p.1327.

29.YIP, K.H., SMALES, R.J., KAIDONIS, J.A., Int. J. Prosthodont, 17, no. 3,2004

30.BEUN, S.B., GLORIEUX, T.R.S., DEVAUX, J., VREVEN, J., LELOUP, G.T., Dental Materials, 23, no.1, 2007, p. 51.

31.MOTA, E.G., WEISS, A., SPOHR, A.M., OSHIMA, H.M.S., NOGARETT DE CARVALHO, L.M., Rev. Odonto. Cienc., 26, no.2, 2011, p. 151.

32.LOHBAUER, U., FRANKENBERGER, R., KRÄMER, N., PETSCHELT, A., Journal of Biomedical Materials Research Part B: Applied Biomaterials, 76 B, no. 1, 2006, p. 114.

33.NICA, I., STOLERIU, S., IOVAN, G., PANCU, G., URSU, L., GEORGESCU, A., ANDRIAN, S., International J ournal of Medical Dentistry, 22, no. 4, 2018, p. 358.

34.TOFAN, N., ANDRIAN, S., NICA, I., STOLERIU, S., TOPOLICEANU, C., CHELARIU, R., BOLAT, M., PANCU, G., Rev. Chim., (Bucharest) 67, no. 6, 2016, p. 1144.

35.ESQUIVEL-UPSHAW, J.F., DIENG, F.Y., CLARK, A.E., NEAL, D., ANUSAVICE, K.J., J. Dent. Res., 92, no. 5, 2013, p. 467.

36. WONGKHANTEE, S., PATANAPIRADEJ, V., MANEENUT, C., TANTBIROJN, D., J. Dent., 34, no. 3, 2006, p. 20.

37.NICA, I., IOVAN, G., GHIORGHE, C.A., STOLERIU, S., PANCU, G., ANDRIAN, S., Romanian Journal of Oral Rehabilitation, 7, no. 4, 2015, p. 37.

38.ILIE, N., HICKEL, R., Clin. Oral Investig., 13, 2009, p. 427.

39.NICA, I., CIMPOESU, N., RUSU, V., ANDRONACHE, M., STEFANESCU, C., Mat. Plast., 49, no.2, 2012, p. 176.

40.KOENEMAN, B.A., ZHANG, Y., WESTERHOFF, P., CHEN, Y., CRITTENDEN, J.C., CAPCO, D.G., Cell. Biol. Toxicol., 26, 2009, p. 225. 41.KIM, K.H., ONG, J.L., OKUNO, O., J. Prosthet. Dent., 87, 2002, p. 642.

42.YUKITANI, W., HASEGAWA, T., ITOH, K., HISAMITSU, H., WAKUMOTO, S., Oper. Dent., 22, 1997, p. 242.

43.TIBA, A., CHARLTON, D.G., VANDEWALLE, K.S., RAGAIN, J.C. J r., J . Dent., 33, 2005, p. 757.

44.BLACKHAM, J.T., VANDEWALLE, K.S., LIEN, W., Oper. Dent., 34, 2009, p. 697.

45. BRAEM, M., FINGER, W., VAN DOREN, V.E., LAMBRECHTS, P., VANHERLE, G., Dent. Mater., 5, 1989, p. 346.

46.MORAES, R.R., RIBEIRO, D.S., KLUMB, M.M., BRANDT, W.C., CORRER-SOBRINHO, L., BUENO, M., Braz. Oral Res., 22, 2008, p. 112.

47.FERRACANE, J.L., Dent. Mater., 22, 2006, p. 211.

48.BAUER, H., ILIE, N., Dent. Mater. J., 32, 2013, p. 592.

49.CESAR, P.F., MIRANDA, W.G. JR., BRAGA, R.R., J. Prosthet. Dent., 86, 2001, p. 289.

50.SIDERIDOU, I.D., KARABELA, M.M., BIKIARIS, D.N, Dent. Mater., 23, 2007, p. 1142.

51.HO, C.T., VIJAYARAGHAVAN, T.V., LEE, S.Y., TSAI, A., HUANG, H.M., PAN, L.C., J. Oral Rehabil., 28, 2001, p. 658.

Manuscript received: 6.03 .2019 